\title{
Pengaruh latihan mandiri dalam rangka pembatasan kegiatan masyarakat: study kasus atlet pencak silat Kabupaten Karawang
}

\author{
Rian Triprayogo ${ }^{1 *}$, Sendy Mohamad Anugrah ${ }^{1}$, Ardhika Falaahudin $^{2}$, Dody Tri Iwandana $^{2}$, \\ Rifqi Festiawan ${ }^{3}$ \\ ${ }^{1}$ Program Studi Ilmu Keolahragaan, Fakultas Kedokteran Universitas Sultan Ageng Tirtayasa \\ ${ }^{2}$ Program Studi Ilmu Keolahragaan, Universitas Mercu Buana Yogyakarta \\ ${ }^{3}$ Program Studi Pendidikan Jasmani Kesehatan dan Rekreasi, Universitas Jenderal Soedirman \\ * Corresponding Author. E-mail: riantriprayogo@untirta.ac.id
}

Received: August 14,2021; Accepted: September 13, 2021; Published: September 25, 2021

\begin{abstract}
Abstrak: Pembatasan kegiatan masyarakat akibat penyebaran virus Covid-19 telah mengubah olahraga di Indonesia sehingga memaksa para atlet untuk melakukan latihan mandiri di tempat tinggalnya masingmasing dengan program latihan yang dibuat oleh para pelatih. Tujuan penelitian ini adalah menggambarkan serta membandingkan kapasitas aerobik, aspek kelincahan, dan daya tahan otot lokal atlet pencak silat sebelum dan sesudah masa latihan mandiri. Metode penelitian yang digunakan adalah experimen dengan melibatkan 12 atlet pencak silat putra kategori tanding Kabupaten Karawang. Hasil penelitian menunjukan bahwa terjadi penurunan signifikan pada kapasitas aerobik $(\mathrm{p}=0.025)$ dan performa kelincahan $(0.042)$ namun pada daya tahan otot lokal tidak terdapat perbedaan. Kesimpulan penelitian ini adalah terjadi penurunan pada kapasitas aerobik dan aspek kelincahan pada atlet pencak silat Kabupaten Karawang setelah masa latihan di tempat tinggalnya masing-masing akibat dari pemberlakukan pembatasan kegiatan masyarakat (PPKM), namun pada komponen daya tahan otot-otot lokal tidak terdapat perubahan.
\end{abstract}

Kata Kunci: Covid-19, latihan mandiri, pencak silat, performa atlet

\section{The Effect of Independent Training in Restricting Community Activities: A Case Study of Pencak Silat Athletes in Karawang Regency}

\begin{abstract}
Restrictions on community activities due to the spread of the COVID-19 virus have changed sports in Indonesia, forcing athletes to practice independently in their respective homes with training programs created by their coaches. The purpose of this study was to compare the aerobic capacity, agility aspects, and local muscle endurance of pencak silat athletes before and after the independent training period. The research method used is experiment by involving 12 male pencak silat athletes in the competition category in Karawang Regency. The results showed that there was a significant decrease in aerobic capacity $(p=0.025)$ and agility performance $(0.042)$ but there was no difference in local muscle endurance. The conclusion of this study is that there is a decrease in aerobic capacity and agility aspects in pencak silat athletes in Karawang Regency after a period of training in their respective homes as a result of the implementation of community activity restrictions (PPKM), but in the component of local muscular endurance there is no change.
\end{abstract}

Keywords: Covid-19, performance, independent training.

How to Cite: Triprayogo, R., \& Nugraha, S.M. (2021). Pengaruh latihan mandiri dalam rangka pembatasan kegiatan masyarakat: study kasus atlet pencak silat Kabupaten Karawang. Jurnal Keolahragaan, 9(2), 290-298. doi: https://doi.org/10.21831/jk.v9i2.43260

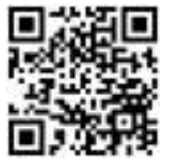

\section{PENDAHULUAN}

Virus yang bernama Coronavirus 2 atau yang biasa disebut Covid-19 hingga tahun 2021 masih terus menyebar dengan cepat ke berbagai negara di seluruh dunia termasuk di Indonesia sehingga menyebabkan pandemi yang tidak terduga. Coronavirus (CoV) adalah bagian dari kelompok virus yang bertanggung jawab untuk musiman memicu sindrom pernapasan akut (SARS) pada manusia dan hewan, (Bélanger et al., 2015). Jadi Corona akan membahayakan bagi manusia apalagi yang memiliki riwayat penyakit. Faktanya, Covid-19 memiliki daya penularan yang tinggi dari manusia ke manusia 
dan satu orang terinfeksi dapat menularkan, rata-rata, ke empat individu lainnya, (Liu et al., 2020). World Health Organization data Coronavirus disease 2019 Covid-19 Situation Report, virus ini mencapai angka kematian yang signifikan, (Organization, 2020). Banyak penduduk di seluruh negara mengalami kematian hingga sekarang.

Di Hong Kong (Cina) pada tahun 2003, virus itu disebabkan 8.098 kasus dengan 774 kematian (9,6\% kematian) dan 858 kematian (34,0\% kematian) di Arab Saudi (Timur Tengah). Saat ini, virus corona "baru" (Sars-CoV-2) telah menjadi terkenal di komunitas ilmiah karena penyebarannya yang lebih cepat dalam skala global yang signifikan. Kemudian World Health Organization atau Organisasi Kesehatan Dunia menyatakan hingga 12 Agustus 2021, Pemerintah Republik Indonesia telah melaporkan 3.774.155 orang terkonfirmasi positif Covid-19. Ada 113.664 kematian terkait Covid-19 yang dilaporkan dan 3.247.715 pasien telah pulih dari penyakit tersebut, (Organization, 2020). Hal ini mengartikan bahwa Indonesia harus melakukan upaya terhadap virus ini, Konsekunsinya, Pemerintah Indonesia dalam upaya mengatasi penyebaran Covid-19 telah melakukan beberapa kebijakan guna memutus penyebaran Covid-19 seperti melakukan pembatasan kegiatan yang mengakibatkan semua kegiatan masyarakat menjadi terbatas kecuali pada sektor esensial seperti di bidang kesehatan dan keuangan. Dalam bidang olahraga, beberapa acara olahraga nasional ditunda atau ditangguhkan seperti pada PON Papua yang seharusnya dipertandingkan tahun 2020 ditunda hingga tahun 2021 penyelenggaraannya.

Aturan pembatasan kegiatan yang dikeluarkan oleh Pemerintah Indonesia mengakibatkan Pemerintah daerah menutup beberapa sarana olahraga umum yang biasa digunakan oleh masyarakat untuk berolahraga maupun digunakan oleh atlet cabang olahraga tertentu untuk berlatih. Penutupan sarana olahraga umum mengakibatkan beberapa atlet yang biasa berlatih di tempat tersebut dan didampingi oleh tim pelatih berpindah tempat latihannya menjadi di tempat tinggalnya masing-masing tanpa didampingi secara langsung oleh tim pelatih namun masih sesuai dengan program latihan yang telah disusun sebelumnya oleh tim pelatih.

Penutupan fasilitas olahraga umum yang biasa digunakan masyarakat dan atlet untuk berolahraga dan latihan oleh Pemerintah telah seusai dengan rekomendasi ataupun protokol kesehatan yang dikeluarkan oleh World Health Organization (WHO). Kesimpulan penelitian terbaru yang dikeluarkan oleh WHO menyebutkan bahwa virus Covid-19 sangat mudah menyebar melalui udara (airborme transmission), selanjutnya penularan melalui udara ini didefinisikan sebagai penyebaran infeksi akibat droplet (aerosol) yang tetap menular ketika tersuspensi di udara dalam jarak waktu yang lama dan penyebaran Covid-19 yang sangat mudah ini terjadi pada ruangan dengan pengaturan ventilasi yang sangat buruk sehingga menyebabkan udara disekitar ruangan tidak mengalami sirkulasi dengan baik (WHO, 2020). Sehingga atas temuan dari World Health Organization (WHO) tersebut menyimpulkan secara umum bahwa dalam masa ketidakpastian akibat pandemi Covid-19, hindari melakukan olahraga atau latihan di ruangan tertutup karena bisa memudahkan penyebaran Covid-19.

Penelitian yang dilakukan di Korea Selatan pada tahun 2020 memiliki kesimpulan bahwa setelah dilakukan pengujian intesnif selam 24 hari di tempat kebugaran di Kota Cheonan (Korea Selatan) menunjukan bahwa sebanyak 112 orang terinfeksi virus sindrom pernafasan akut parah atau Covid-19 selama kurun waktu 24 hari tersebut. Hal ini dikarenakan orang yang terinfeksi virus tersebut mengikuti kelas tari kebugaran dan mengabaikan penggunan protokol kesehatan. Sehingga dalam penelitian tersebut disimpulkan bahwa berolahraga atau melakukan latihan fisik yang intens di fasilitas olahraga umum yang sering dikunjungi oleh masyarakat dapat meningkatkan risiko terinfeksi Covid-19. Dalam penelitian tersebut juga masih disimpulkan bahwa melakukan olahraga berat di ruang terbatas harus diminimalkan selama wabah Covid-19 masih tidak terkendali (Jang et al., 2020).

Penelitan terbaru mengenai penyebaran Covid-19 di tempat kebugaran telah dilakukan di Kota Chicaco Negara Bagian Illinois (Amerika Serikat) pada Maret tahun 2021. Dalam penelitian tersebut ditemukan bahwa kasus penyebaran virus Covid-19 ditemukan diantara 81 orang peserta yang mengikuti kelas olahraga intensistas tinggi yang dilakukan di fasilitas kebugaran di Kota Chicago dengan kondisi ruangan olahraga tidak memiliki sistem sirkulasi udara yang baik. Pada penelitian tersebut 50\% lebih dari total peserta (43 orang) yang hadir pada kelas olahraga dengan intensitas tinggi tersebut terpapar virus Covid-19 yang diakibatkan oleh jarangnya menggunakan masker dan mengabaikan protokol kesehatan ketika proses latihan sedang berlangsung. Sehingga dalam penelitian tersebut, Franced menyimpulkan bahwa masyarakat untuk sementara waktu dalam masa penyebaran wabah virus Covid-19 untuk mengurangi dan menghindari kegiatan olahraga di dalam ruangan, 
adapun jika keadaan memaksa Frances merekomendasikan agar ketika melakukan aktivitas fisik di dalam ruangan harus menggunakan masker dan membatasi jarak dengan individu lainnya. Frances dalam penelitiannya juga merekomendasikan agar melakukan olahraga atau aktivitas fisik di luar ruangan atau olahraga secara virtual supaya terhindar dan mengurangi resiko penularan virus Covid-19 (Lendacki et al., 2021).

Hasil penelitian sebelumnya menyimpulkan bahwa untuk menghindari paparan virus Covid-19 dari orang lain, seorang individu untuk menghindari melakukan olahraga atau aktivitas fisik di dalam ruangan yang memiliki ventilasi udara yang tidak baik secara bersama-sama dalam masa penyebaran wabah Covid-19 seperti saat ini dan merekomendasikan agar melakukakan olahraga atau aktivitas fisik di luar ruangan namun dengan menggunakan masker dan protokol keseahatan yang maksimal (Jang et al., 2020; Lendacki et al., 2021). Beberapa kegiatan olahraga atau aktivitas fisik yang biasa dilakukan di dalam ruangan adalah olahraga zumba, futsal, angkat besi atau angkat berat dan beberapa jenis olahraga martial arts atau olahraga bela diri seperti taekwondo, karate, judo, pencak silat, dan beberapa jenis olahraga bela diri lainnya. Sehingga beberapa jenis olahraga yang biasa dilakukan di dalam ruangan tersebut untuk sementara waktu tidak bisa dilakukan di tempat yang seharusnya. Pencak silat merupakan jenis olahraga bela diri yang latihan dan pertandingannya cenderung dilakukan di dalam ruangan. Pencak silat dalam beberapa penelitian sebelumnya disimpulkan menjadi olahraga bela diri yang lebih populer di negara-negera barat dan sudah mendapatkan pengakuan dari dunia Internasional (Apriantono et al., 2020; Aziz et al., 2002; Soo et al., 2018). Berdasarkan sejarahnya, pencak silat yang merupakan jenis olahraga bela diri yang berasal dari etnis Melayu di Asia Temggara dan digunakan dan dipraktikkan oleh penduduk asli dalam perjuangannya melawan penguasa kolonial atau bangsa penjajah (Aziz et al., 2002). Seiring berjalannya waktu, pencak silat berubah menjadi kegiatan budaya dan digunakan untuk tujuan seremonial dan rekreasi, kemudian setelahnya bentuk seni tradisional ini telah dimodifikasi menjadi olahraga kompetitif yang terstruktur (Aziz et al., 2002; Jusuf et al., 2020)

Badan pengendali dunia olahraga, Federasi Pencak Silat Internasional mencakup negara-negara anggota seperti Amerika Serikat, Jepang dan banyak negara Eropa. Terdapat berbagai kompetisi yang diakui secara internasional seperti Kejuaraan Eropa yang diresmikan pada tahun 1985, Asian Games Tenggara (sejak 1987) dan Kejuaraan Dunia (sejak 1982). Kompetisi atau kejuaran pencak silat dari tingkat anak-anak hingga dewasa dan dari amatir hingga profesional telah diadakan di banyak negara non-tradisional atau yang tidak memiliki sejarah pencak silat seperti Austria, Belgia, Belanda dan Thailand. Sehingga dengan fakta tersebut bahwa partisipasi secara global dalam kompetisi atau kejuaran pencak silat telah meningkat secara substansial dan menunjukkan pengikut dan penerimaan pencak silat di seluruh dunia (Aziz et al., 2002). Walaupun telah dikompetisikan atau dipertandingkan dalam berbagai kelompok umur dan tingkatan level dari atlet amatir hingga atlet profesional atau elit, hingga saat ini olahraga pencak silat belum dipertandingkan di ajang Olimpiade. Sejarah tercipta ketika Even olahraga terbesar di Asia mempertandingkan atau memperlombakan pencak silat pada Asian Games 2018 Jakarta dan Palembang. Pada ajang Asian Games ke-18 tersebut, tuan rumah Indonesia berhasil memecahkan rekor dengan memborong total 15 medali dengan rincian 14 medali emas dan 1 medali perunggu.

Pencak silat merupakan jenis olahraga martial art sports yang terbagi menjadi dua kategori, yakni kategori seni dan kategori tanding. Penelitian sebelumnya menunjukan bahwa pencak silat kategori tanding merupakan jenis olahraga yang memiliki karakterisitik aerobik dan anerobik yang tinggi sehingga menjadikan tuntutan tinggi dalam aspek fisik, teknik dan mental dalam setiap pertandingannya, (Aziz et al., 2002) . Tuntunan komponen fisik yang tinggi mengharuskan atlet pencak silat melakukan latihan yang terprogram dengan maksimal sehingga menghasilkan atlet pencak silat yang beprestasi. Namun, dengan diberlakukannya pembatasan kegiatan masyarakat menyebabkan tempat latihan yang biasa digunakan harus ditutup sehingga mengharuskan atlet untuk melakukan latihan secara mandiri di tempat tinggalnya masing-masing dengan program latihan yang telah disusun oleh tim pelatih. Hal ini untuk menghindari dan meminimalkan resiko atlet dan pelatih hingga pengurus cabang olahraga pencak silat terpapar virus Covid-19. Mengingat tempat latihan dan pertandingan pencak silat cenderung menggunakan area di dalam ruangan dan menurut penelitian sebelumnya tempat di dalam ruangan dengan ventilasi udara yang tidak maksimal merupakan tempat yang mudah untuk penyebaran virus Covid-19 (Jang et al., 2020; Lendacki et al., 2021). Sehingga 
tempat latihan di dalam ruangan dalam masa pandemi Covid-19 harus dihindari untuk sementara waktu.

Program latihan yang telah disusun mengharuskan atlet melakukan program latihan tersebut. Namun kurangnya pengawasan terhadap latihan menyebabkan program latihan yang telah disusun menjadi tidak maksimal. Beberapa penelitian sebelumnya menyimpulkan bahwa pengurangan intensitas latihan menyebabkan penurunan adaptasi fisiologis dan neuromuskular pada atlet dan bahkan bisa menyebabkan cedera (Eirale et al., 2020; Mon-1 et al., 2020). Beberapa penelitian lainnya menyebutkan bahwa pengurangan intensitas latihan dalam kurun waktu 3-8 minggu akan mengakibatkan efek negatif pada komposisi tubuh, kapasitas aerobik, kemampuan kelincahan serta kemampuan daya tahan otot-otot lokal di dalam tubuh, (Festiawan, Hooi, et al., 2021; Koundourakis et al., 2014; Mon-l et al., 2020; Mujika \& Padilla, 2000). Untuk mewujudkan latihan aerobik atau latihan seperti sepeda, treadmill dan dayung, juga menjadi pilihan bagi para atlet yang memiliki peralatannya (Kamaludin et al., 2020).

Latihan yang dikenal sebagai lompat jack, lompat tali, antara lain juga pilihan, jika kondisi muskuloskeletal memungkinkan. Ini kegiatan dapat dilakukan terus menerus misalnya 30 menit terus menerus asalkan total akumulasi dalam minggu adalah 150 menit, seperti yang disarankan oleh ACSM, (Festiawan, 2020; Garber et al., 2011; Joy, 2020). Selain itu, latihan penerapan resistensi manual atau latihan ketahanan diri bisa menjadi alternatif seperti senam untuk memvariasikan rangsangan fisiologis serta untuk memecahkan monoton psikologis, (Chulvi-Medrano et al., 2017; Dorgo et al., 2009; Serrau et al., 2012). Sukses dalam olahraga meliputi dari program seleksi atlet, program latihan dan evaluasi kinerja atlet. Dalam proses penyeleksian atlet olahraga khususnya pencak silat, penting untuk seorang pelatih untuk memonitor status kebugaran atletnya setelah hanya melakukan latihan mandiri akibat dari dibatasinya kegiatan masyarakat oleh Pemerintah sehingga beberapa sarana olahraga tempat berlatih atlet terpaksa ditutup. Oleh karena itu penelitian ini bertujuan untuk mengetahui perbedaan kapasitas aerobik, aspek kelincahan, dan daya tahan otot-otot lokal setelah atlet pencak silat daerah Kabupaten Karawang melakukan latihan mandiri di tempat tinggalnya masing-masing. Sehingga dengan penelitian ini diharapkan mampu memberikan pemahaman yang lebih objektif dalam program talented scoutin dan performa atlet.

\section{METODE}

Penelitian yang telah dilakukan merupakan penelitian eksperimen dan untuk memperoleh data yang diinginkan dan sesuai maka dalam penelitian ini menggunakan teknis tes. Subjek penelitian ini terdiri dari 12 orang yang merupakan atlet pencak silat putra kategori tanding asal Kabupaten Karawang. Subjek penelitian merupakan atlet pencak silat yang menghabiskan rata-rata 10 jam latihan per minggunya dan mempunyai pengalaman di olahraga pencak silat selama 5 tahun. Seluruh subjek penelitian dalam kondisi sehat, tanpa penyakit kardiovaskular, asthma, dan tidak merokok. Pengukuran tinggi badan pada penelitian in menggunakan alat stadiometer, pengukuran berat badan dan indeks massa tubuh menggunakan alat Scan Body Fat Omron Carada, pengukuran dilakukan 2 kali. Pengukuran kapasitas aerobik menggunakan tes lapangan berupa bleep test. Pengukuran aspek kelincahan menggunakan shutle-run $4 \times 10$ meter, dan pengukuran data tahan otot perut menggunakan sit up test, daya tahan otot lengan menggunakan push up test, dan daya tahan otot tungkai menggunakan hurdle jump test. Data yang ditampilkan pada penelitian ini berupa nilai rata-rata dan standar deviasi. Penelitian ini menganalisis hubungan latihan mandiri menggunakan analisis paired Ttest. Analisis statistik menggunakan aplikasi SPSS versi 22 dengan taraf signifikansi $\mathrm{p}<0,05$.

\section{HASIL DAN PEMBAHASAN}

Pada penelitan yang telah dilakukan umur, tinggi badan, berat badan dan IMT subjek penelitian masing-masing ada1 ah $20.40 \pm 1.80$ tahun, $171.28 \pm 4.56 \mathrm{~cm}, 63.18 \pm 4.85 \mathrm{~kg}$, dan $21.56 \pm 3.43$. Pada tabel 1 menyajikan data rata-rata kapasitas aerobik dan kelincahan sebelum dan sesudah pemberlakukan pembatasa kegiatan masyarakat yang menyebabkan subjek penelitian melakukan latihan mandiri di tempat tinggalnya masing-masing. 
Jurnal Keolahragaan 9 (2), 2021 - 294

Rian Triprayogo, Sendy Mohamad Anugrah, Ardhika Falaahudin, Dody Tri Iwandana, Rifqi Festiawan

Tabel 1. Data Kapasitas Aerobik subjek penelitian

\begin{tabular}{cccccc}
\hline \multirow{2}{*}{ Variabel } & \multicolumn{2}{c}{ Sebelum Latihan Mandiri } & \multicolumn{2}{c}{ Sesudah Latihan Mandiri } & \multirow{2}{*}{$\mathrm{p}$} \\
\cline { 2 - 5 } & Rata-rata & SD & Rata-rata & SD & \\
\hline Kapasitas Aerobik & 54.48 & 1.81 & 51.72 & 1.31 & $0.025^{*}$ \\
Kelincahan & 9.12 & 2.31 & 10.96 & 2.78 & $0.042^{*}$ \\
\hline
\end{tabular}

Ket : * signifikan berbeda , $P<0.05$

Pada tabel 1 menyajikan data rata-rata kapasitas daya tahan otot lokal sebelum dan sesudah pemberlakukan pembatasa kegiatan masyarakat yang menyebabkan subjek penelitian melakukan latihan mandiri di tempat tinggalnya masing-masing.

Tabel 2. Data daya tahan otot lokal subjek penelitian

\begin{tabular}{cccccc}
\hline \multirow{2}{*}{ Variabel } & \multicolumn{2}{c}{ Sebelum Latihan Mandiri } & \multicolumn{2}{c}{ Sesudah Latihan Mandiri } & $\mathrm{p}$ \\
& Rata-rata & SD & Rata-rata & SD & 7.82 \\
Push-up & 40.82 & 6.68 & 39.56 & 0.548 \\
Sit Up & 32.62 & 3.81 & 31.86 & 4.31 & 0.648 \\
Hurdle Jump & 92.56 & 7.97 & 90.84 & 8.51 & 0.780 \\
\hline
\end{tabular}

Ket : * signifikan berbeda, $\mathrm{P}<0.05$

Pemberlakukan Pembatasan Kegiatan Masyarakat (PPKM) tidak hanya berdampak pada kegiatan ekonomi masyarakat, namun berdampak juga pada kegiatan-kegiatan olahraga termasuk di dalamnya kegiatan pemusatan latihan. Beberapa sarana olahraga yang dijadikan tempat pemusatan latihan harus ditutup oleh Pemerintah Daerah akibat dari kebijakan Pemerintah Pusat guna memutus penyebaran virus Covid-19. Sehingga dengan kebijakan tersebut perlu dilakukan perubahan tempat latihan yang tadinya terpusat di sarana olahraga menjadi melakukan latihan di tempat tinggal masingmasing atau latihan mandiri. Pada penelitian ini bertujuan untuk membandingkan kapasitas aerobik, aspek kelincahan, dan daya tahan otot lokal atlet pencak silat putra daerah Kabupaten Karawang sebelum dan sesudah diberlakukannya PPKM.

Hasil penelitian menunjukan bahwa terdapat perbedaan signifikan pada kapasitas aerobik dan aspek kelincahan sebelum dan sesudah atlet pencak silat melakukan latihan mandiri pasca diberlakukannya PPKM. Pada penelitian ini ditemukan bahwa atlet pencak silat mengalami penurunan pada kapasitas aerobik dan aspek kelincahan sehingga latihan mandiri yang telah diprogramkan oleh tim pelatih dan harus dilaksanakan oleh atlet pencak silat putra selama diberlakukannya PPKM berpengaruh positif terhadap kondisi kebugaran atlet. Hasil penelitian ini tidak jauh berbeda dengan penelitian sebelumnya yang menyimpulkan bahwa kapasitas aerobik dan aspek kelincahan atlet bola tangan asal Spanyol dan taekwondo asal Iran mengalami penurunan yang signifikan setelah melakukan proses isolasi kemudian melakukan latihan mandiri di tempat tinggalnya masing-masing, (Mon-l et al., 2020; Ozrudi et al., 2021). Dalam penelitian tersebut dijelaskan bahwa beberapa faktor yang mengakibatkan penurunan kapasitas aerobik dan aspek kelincahan adalah penurunan intensitas latihan selama latihan mandiri yang dilakukan oleh atlet, kurangnya pengawasan secara langsung oleh tim pelatih dan kurangnya peralatan atau ruangan yang tidak cukup untuk melakukan latihan, (Mon-l et al., 2020; Ozrudi et al., 2021). Selanjutnya, tempat latihan yang terbatas mengakibatkan pembatasan ruang gerak sehingga tidak memungkinkan bagi atlet untuk melakukan latihan meningkatkan kapasitas aerobik dan aspek kelincahan, (Kraemer et al., 2002; Mario A. Cardoso Marques, 2006; Mon-1 et al., 2020). Hal ini terjadi pada atlet pencak silat Kabupaten Karawang yang tempat latihan mandirinya selama PPKM tidak memungkinkan untuk melakukan latihan daya tahan kardiovaskular sehingga kapasitas aerobik dan kelincahan atlet cenderung mengalami penurunan setelah dilakukan pengetesan kembali setelah selesai PPKM.

Pada penelitian ini diketahui bahwa kapasitas aerobik atlet pencak silat Kabupaten Karawang berada pada rentang nilai $51-54 \mathrm{ml} / \mathrm{kg} / \mathrm{min}$. Hasil penelitian ini memiliki kesamaan dengan beberapa penelitian sebelumnya yang menggunakan kelompok atlet pencak silat level elit dan profesional. Dalam penelitian tersbut disimpulkan bahwa atlet pencak silat level elite memiliki rentang nilai kapasitas aerobik antara 50-58 ml $/ \mathrm{kg} / \mathrm{min}$ (Apriantono et al., 2020; Aziz et al., 2002; Soo et al., 2018). Tingginya nilai kapasitas aerobik yang dimiliki oleh atlet pencak silat karena beban latihan yang dilakukannya juga besar mengingat olahraga pencak silat merupakan olahraga beladiri dengan karakteristik aerobik dan anaerobik (Aziz et al., 2002), sehingga dengan karakteristik aerobik dan 
anerobik atlet pencak silat dituntut untuk memiliki kapasitas aerobik yang besar atau memiliki kondisi fisik yang sangat prima.

Sama seperti pengetesan kapasitas aerobik dan aspek kelincahan. Sebelum diberlakukannya PPKM, dilakukan pengetesan terhadap atlet pencak silat putra dengan hasilnya ditunjukan pada tabel 2 berupa nilai tes push-up, sit-up, dan hurdle jump. Kemudian pada tabel yang sama ditampilkan nilai kapasitas tes push-up, sit-up, dan hurdle jump pada atlet pencak silat seesudah diberlakukannya PPKM dan melakukan latihan mandiri di tempat tinggalnya masing-masing.

Hasil penelitian ini menunjukan bahwa tidak terdapat perbedaan signifikan pada variabel kekuatan otot-otot lokal seperti push-up, sit-up, dan hurdle jump sebelum dan sesudah atlet pencak silat melakukan latihan mandiri. Pada penelitian ini diketahui bahwa atlet pencak silat tidak mengalami perubahan pada push-up, sit-up, dan hurdle jump sehingga latihan mandiri yang telah diprogramkan oleh tim pelatih dan harus dilaksanakan oleh atlet pencak silat putra selama diberlakukannya PPKM berpengaruh untuk mempertahankan kemampuan daya tahan otot lokal. Penelitian yang telah dilakukan tidak jauh berbeda dengan hasil penelitian sebelumnya yang menyimpulkan bahwa melakukan latihan ketahanan pada otot-tot tertentu selama dua hingga tiga kali dalam satu minggu selama 2 bulan dapat meminimalkan hilangnya fungsi pada kardiorespiratori dan otot-otot tertentu, atau secara lebih khusus mempertahankan kemampuan daya tahan otot-otot lokal bahkan meningkatkan kekuatan maksium jika latihan ketahanan tersebut dibantu dengan peralatan yang memadai (Mon-1 et al., 2020; Skoufas et al., 2008). Walaupun pada penelitian ini tidak menemukan peningkatan signnifikan pada daya tahan otot lokal atlet pencak silat karena ketika para atlet melakukan latihan mandiri hanya menggunakan beban tubuh sendiri tanpa peralatan tambahan. (Festiawan, Hoi, et al., 2021; Giustino et al., 2020; Leônidas de Oliveira Neto, Hassan Mohamed Elsangedy \& , Cauê Vazquez La Scala Teixeira, Dave G Behm, 2020).

Penyebaran Covid-19 yang masih fluktuatif perkembangannya, mengakibatkan kepastian kapan berakhirnya situasi seperti ini masih belum diketahui secara pasti sehingga menyebabkan Pemerintah Indonesia melakukan beberapa upaya pencegahan penyebaran apabila dalam kurun waktu tertentu kasus Covid-19 mengalami kenaikan yang signfikan dengan cara melakukan kebijakan berupa pemberlakukan pembatasan kegiatan masyarakat (PPKM) sangat ketat yang mengakibatkan salah satunya adalah penutupan tempat olahraga umum di dalam ruangan yang biasa digunakan oleh masyarakat untuk berolahraga atau untuk atlet melakukan latihan atau pertandingan. Sedangkan apabila kasus Covid-19 mengalami penuruan dalam kurun waktu tertentu maka Pemerintah Indonesia melakukan pelonggaran pengetatan PPKM dengan membuka kembali akses akses tempat umum masyarakat yang salah satunya adalah membuka tempat olahraga umum di dalam ruangan namun dengan kondisi tertentu, seperti harus memaki masker, menjaga jarak antar individu, tidak berkerumun, dan membatasi kapasitas tempat olahraga umum tersebut hanya $25 \%$ hingga $50 \%$ dari kapasitas maksimal yang diperbolehkan.

Pembatasan kapasitas hingga peniadaan kegiatan olahraga, latihan dan pertandingan dalam tempat olahraga umum di dalam ruangan merupakan pilihan yang sangat tepat mengingat penyebaran Covid-19 masih fluktuatif di Indonesia. Penutupan tempat olahraga umum di dalam ruangan ini diperkuat dengan penelitian sebelumnya yang memiliki kesimpulan bahwa berolahraga atau melakukan latihan fisik yang intens di fasilitas olahraga umum yang sering dikunjungi oleh masyarakat dapat meningkatkan risiko terinfeksi Covid-19. Dalam penelitian tersebut juga masih disimpulkan bahwa melakukan olahraga berat di ruang terbatas harus diminimalkan selama wabah Covid-19 masih tidak terkendali (Jang et al., 2020). Penelitan lainnya menyimpulkan bahwa baik individu sehat ataupun atlet elit atau amatir untuk sementara waktu dalam masa penyebaran wabah virus Covid-19 untuk mengurangi dan mengghindari kegiatan olahraga di dalam ruangan. Adapun jika keadaan memaksa, dalam penelitian tersebut menyarankan agar ketika melakukan aktivitas fisik di dalam ruangan harus menggunakan masker dan membatasi jarak dengan individu lainnya. Dalam penelitian tersebut juga merekomendasikan dan mendorong agar individu sehat ataupun atlet elit atau amatir untuk sementara waktu melakukan latihan atau aktivitas fisik di luar ruangan atau olahraga secara virtual supaya terhindar dan mengurangi resiko penularan virus Covid-19 dengan motivasi yang tetap terjaga (Antoni et al., 2021; Lendacki et al., 2021).

Mengingat wabah Covid-19 masih belum pasti kapan berakhirnya, maka situasi seperti penutupan dan pembatasan tempat olahraga umum di dalam ruangan masih bisa terjadi setiap waktu mengikuti kebijakan dari Pemerintah Pusat kepada Pemerintah Daerah. Oleh karena itu untuk 
memaksimalkan tempat olahraga umum di dalam ruangan yang dibatasi kapasitasnya, maka diperlukan langkah langkah yang tepat agar tempat olahraga umum di dalam ruangan yang dijadikan tempat latihan atlet tidak menjadi episentrum penyebaran Covid-19 yang baru. Adapun protokol kesehatan yang bisa digunakan apabila tempat olahraga umum dalam ruangan dijadikan tempat latihan kembali atlet menurut penelitian terbaru yang sudah terbukti meminimalkan penyebaran virus Covid19 di tempat atau fasilitas olahraga umum di dalam ruangan adalah dengan melakukan pengecekan suhu tubuh dan penggunaan hand sanitizer untuk masing-masing atlet sebelum memasuki tenpat latihan, menggunakan alat penejernih atau penyaring udara yang minimal 2 di ruangan tersebut, atlet yang mengikuti sesi latihan dibagi menjadi beberapa kelompok dalam waktu yang berbeda guna menghindari kerumunan dengan maksimal atlet yang mengikuti sesi latiihan sebanyak 8 orang, mengatur jarak antara atlet satu dengan atlet setidaknya 6 kaki ( 2 meter lebih) dengan tanda persegi panjang di lantai sehingga setiap orang berada di dalam areanya masing-masing, durasi latihan dikurangi dari 60 menit menjadi hanya 30 menit, semua lantai di fasilitas olahraga umum di dalam ruangan tersebut wajib dibersihkan dengan dipel menggunakan cairan desinfektan setiap hari, semua permukaan sentuh di fasilitas olahraga umum di dalam ruangan tersebut disanitasi tiap sesi latihan atlet, ruang ganti di fasilitas olahraga umum di dalam ruangan tersebut hanya digunakan dalan keadaan darurat, kamar mandi di fasilitas olahraga umum di dalam ruangan tersebut dibatasi kegunannya dan hanya digunakan dalam keadaan darurat, dan apabila memungkinkan setiap sesi latihan para atlet tetap memakai maskernya (Cilhoroz \& DeRuisseau, 2021).

Penelitian yang telah dilakukan memiliki beberapa keterbatasan. Pertama, persepektif psikologis subjek penelitian tidak diukur dalam penelitian ini. Pengukuran perspektif psikologis ini merupakan hal yang sangat penting karena menurut hasil beberapa penelitian sebelumnya menyimpulkan bahwa kondisi Covid-19 yang tidak menentu seperti saat ini mempengaruhi perasaan atlet yang mengakibatkan kondisi psikologis terganggu dan mempengaruhi kesehatan mental atlet secara signifikan (Bisciotti et al., 2020; Eirale et al., 2020; Mon-1 et al., 2020; Pillay et al., 2020). Kedua, subjek penelitian selama melakukan latihan mandiri tidak menggunakan alat heart rate monitor sehingga penilaian latihan subjek penelitian lebih subjektif.

\section{SIMPULAN}

Berdasarkan hasil dan pembahasan pada penelitian ini maka kesimpulan penelitian yang telah dilakukan adalah terjadi penurunan pada kapasitas aerobik dan aspek kelincahan pada atlet pencak silat Kabupaten Karawang setelah melakukan latihan mandiri di tempat tinggalnya masing-masing akibat dari pemberlakukan pembatasan kegiatan masyarakat (PPKM), namun pada komponen daya tahan otot-otot lokal tidak terdapat perubahan. Hasil penelitian ini diharapkan bisa menjadi rujukan agar para pelatih lebih memperhatikan program latihan mandiri para atletnya mengingat pemberlakukan kegiatan masyarakat yang dilakukan oleh Pemerintah guna menurunkan penyebaran virus Covid-19 membatasi akses tempat latihan di sarana olahraga tempat dilakukannya latihan terpusat menjadi terbatas sehingga program latihan hanya dilakukan di tenpat tinggalnya masingmasing yang cenderung tidak maksimal. Perlu adanya penelitian lanjut dengan menggunakan sampel yang lebih banyak dan dari cabang olahraga lain sehingga data yang dihasilkan semakin beragam.

\section{DAFTAR PUSTAKA}

Antoni, M. S., Guntur, G., Festiawan, R., Nugraha, A. I., \& Nurhadi, F. I. (2021). Rockport walking fitness test apps: application of cardiorespiration fitness test with rockport method android based. MEDIKORA, 20(1). https://doi.org/10.21831/medikora.v20i1.34960

Apriantono, T., Herman, I., Winata, B., Hasan, M. F., Juniarsyah, A. D., Ihsani, S. I., Hidayat, I. I., Safei, I., \& Hindawan, I. (2020). Differences of physiological characteristics of taekwondo junior players vs pencak silat junior players. Physical Activity Review, 8(2), 9-15. https://doi.org/10.16926/par.2020.08.16

Aziz, A. R., Tan, B., \& Teh, K. C. (2002). Research article PHYSIOLOGICAL RESPONSES DURING MATCHES AND PROFILE OF ELITE PENCAK SILAT EXPONENTS. Journal of Sports Science and Medicine, 1(147), 147-155.

Bélanger, J. J., Pierro, A., Barbieri, B., Carlo, N. A. De, Falco, A., \& Arie, W. (2015). Article 
information: Users who downloaded this article also downloaded:

Bisciotti, G. N., Eirale, C., Corsini, A., Baudot, C., Saillant, G., \& Chalabi, H. (2020). Return to football training and competition after lockdown caused by the COVID-19 pandemic: Medical recommendations. Biology of Sport, 37(3), 313-319. https://doi.org/10.5114/biolsport.2020.96652

Chulvi-Medrano, I., Rial, T., Cortell-Tormo, J. M., Alakhdar, Y., Teixeira, C. V. L. S., Masiá-Tortosa, L., \& Dorgo, S. (2017). Manual resistance versus conventional resistance training: Impact on strength and muscular endurance in recreationally trained men. Journal of Sports Science and Medicine, 16(3), 343-349.

Cilhoroz, B. T., \& DeRuisseau, L. R. (2021). Safety protocols in an exercise facility result in no detectable sars-CoV2 spread: A case study. Physiological Reports, 9(14), 1-6. https://doi.org/10.14814/phy2.14967

Dorgo, S., King, G. A., \& Rice, C. A. (2009). The effects of manual resistance training on improving muscular strength and endurance. Journal of Strength and Conditioning Research, 23(1), 293303. https://doi.org/10.1519/JSC.0b013e318183a09c

Eirale, A. C., Bisciotti, G., Corsini, A., \& Baudot, C. (2020). Medical recommendations for homeconfined footballers ' training during the COVID-19 pandemic : from evidence to practical application. Biol Sport., 37(2), 203-207.

Festiawan, R. (2020). Pendekatan Teknik dan Taktik: Pengaruhnya Terhadap Keterampilan Bermain Futsal. Gelanggang Olahraga: Jurnal Pendidikan Jasmani Dan Olahraga, 3(2), 143-155. https://doi.org/https://doi.org/10.31539/jpjo.v3i2.1080

Festiawan, R., Hoi, L. B., Siswantoyo, Ngadiman, Kusuma, I. J., Heza, F. N., Wahono, B. S., Wijayanto, A., \& Sumartiningsih, S. (2021). High-Intensity Interval Training, Fartlek Training \& Oregon Circuit Training: What Are the Best Exercises To Increase Vo2 Max? Annals of Tropical Medicine \& Public Health, 24(03), 0-10. https://doi.org/10.36295/asro.2021.24363

Festiawan, R., Hooi, L. B., Widiawati, P., Yoda, I. K., S, A., Antoni, M. S., \& Nugroho, A. I. (2021). The Problem-Based Learning: How the effect on student critical thinking ability and learning motivation in COVID-. Journal Sport Area, 6(2), 231-243.

Garber, C. E., Blissmer, B., Deschenes, M. R., Franklin, B. A., Lamonte, M. J., Lee, I. M., Nieman, D. C., \& Swain, D. P. (2011). Quantity and quality of exercise for developing and maintaining cardiorespiratory, musculoskeletal, and neuromotor fitness in apparently healthy adults: Guidance for prescribing exercise. Medicine and Science in Sports and Exercise, 43(7), 13341359. https://doi.org/10.1249/MSS.0b013e318213fefb

Giustino, V., Parroco, A. M., Gennaro, A., Musumeci, G., Palma, A., \& Battaglia, G. (2020). Physical Activity Levels and Related Energy Expenditure during COVID-19 Quarantine among the Sicilian Active Population: A Cross-Sectional Online Survey Study. Sustainability, 12(4356).

Jang, S., Han, S. H., \& Rhee, J. Y. (2020). Cluster of Coronavirus disease associated with fitness dance classes, South Korea. Emerging Infectious Diseases, 26(8), 1917-1920. https://doi.org/10.3201/eid2608.200633

Joy. (2020). Staying Active During COVID-19.

Jusuf, J. B. K., Raharja, A. T., Mahardhika, N. A., \& Festiawan, R. (2020). Pengaruh teknik effleurage dan petrissage terhadap penurunan perasaan lelah pasca latihan Pencak Silat. Jurnal Keolahragaan, 8(1), 1-8. https://doi.org/10.21831/jk.v8i1.30572

Kamaludin, Ngadiman, Festiawan, R., Kusuma, I. J., \& Febriani, A. R. (2020). Pengembangan Permainan Pecah Piring Sintren : Pemanfaatan Olahraga Tradisional Pada Pembelajaran untuk Meningkatkan Kemampuan Motorik Kasar Anak. TEGAR: Journal of Teaching Physical Education in Elementary SchoolJournal of Teaching Physical Education in Elementary School, 3(5), 37-45. 
Rian Triprayogo, Sendy Mohamad Anugrah, Ardhika Falaahudin, Dody Tri Iwandana, Rifqi Festiawan

Koundourakis, N. E., Androulakis, N. E., Malliaraki, N., Tsatsanis, C., Venihaki, M., \& Margioris, A. N. (2014). Discrepancy between Exercise Performance, Body Composition, and Sex Steroid Response after a Six-Week Detraining Period in Professional Soccer Players. 9(2). https://doi.org/10.1371/journal.pone.0087803

Kraemer, W. J., Koziris, L. P., Ratamess, N. A., Bride, N. T. T. C., Fry, A. C., Gordon, S. E., Volek, J. S., French, D. N., Sharman, M. J., Rubin, M. R., Go, A. N. A. L., Lynch, J. M., Izquierdo, M., Newton, R. U., \& Fleck, S. J. (2002). Detraining Produces Minimal Changes in Physical Performance and Hormonal Variables in Recreationally Strength-Trained Men. Journal of Strenght and Condutioning Research, 16(3), 373-382.

Lendacki, F. R., Teran, R. A., Gretsch, S., Fricchione, M. J., \& Kerins, J. L. (2021). COVID-19 Outbreak Among Attendees of an Exercise Facility - Chicago, Illinois, August-September 2020. MMWR Surveillance Summaries, 70(9), 321-325. https://doi.org/10.15585/mmwr.mm7009e2

Leônidas de Oliveira Neto, Hassan Mohamed Elsangedy, V. D. de O. T., \& , Cauê Vazquez La Scala Teixeira , Dave G Behm, M. E. D. S.-G. (2020). Brazilian Journal of Exercise Physiology. Rev Bras Fisiol Exerc, 19(2suol), 9-19.

Liu, Y., Gayle, A. A., Wilder-Smith, A., \& Rocklöv, J. (2020). The reproductive number of COVID19 is higher compared to SARS coronavirus. Journal of Travel Medicine, 27(2), 1-4. https://doi.org/10.1093/jtm/taaa021

Mario A. Cardoso Marques, J. Jo. G. B. (2006). In Season Resistance Training and Detraining in Professional Team Handball Players. Ournal of Strenght and Condutiioning Research, 20(3), 563-571.

Mon-1, D., De, A., Riaza, R., Gal, H., \& Roman, I. R. (2020). The Impact of Covid-19 and the Eff ect of Psychological Factors on Training Conditions of Handball Players. 1-14.

Mujika, I., \& Padilla, S. (2000). Detraining : Loss of Training-Induced Physiological and Performance Adaptations . Part II. Sports Med, 30(3), 145-154.

Organization, W. H. (2020). Update on Coronavirus Disease in Indonesia. Novel Coronavirus.

Ozrudi, M. F., Faghanpou, S., Goli, R. G., \& Podrigalo, L. (2021). Effect of depression among taekwondo students and its relationship with negative events due to COVID-19. PHYSICAL EDUCATION OF STUDENT. https://doi.org/10.15561/20755279.2021.0102

Pillay, L., Janse van Rensburg, D. C. C., Jansen van Rensburg, A., Ramagole, D. A., Holtzhausen, L., Dijkstra, H. P., \& Cronje, T. (2020). Nowhere to hide: The significant impact of coronavirus disease 2019 (COVID-19) measures on elite and semi-elite South African athletes. Journal of Science and Medicine in Sport, 23(7), 670-679. https://doi.org/10.1016/j.jsams.2020.05.016

Serrau, V., Driss, T., Vandewalle, H., Behm, D. G., Lesne-Chabran, E., \& Le Pellec-Muller, A. (2012). Muscle activation of the elbow flexor and extensor muscles during self-resistance exercises: Comparison of unilateral maximal cocontraction and bilateral self-resistance. Journal of Strength and Conditioning Research, 26(9), 2468-2477.

https://doi.org/10.1519/JSC.0b013e31823bc0a2

Skoufas, D., Skoufa, E., Christodoulidis, T., \& Papadopoulou, S. (2008). The effect of arm and forearm loading on the throwing velocity of novice handball player : influences during training and detraining. Train, 11, 1-11.

Soo, J., Woods, C. T., Arjunan, S. P., Aziz, A. R., \& Ihsan, M. (2018). Identifying the performance characteristics explanatory of fight outcome in elite Pencak Silat matches. International Journal of Performance Analysis in Sport, 18(6), 973-985. https://doi.org/10.1080/24748668.2018.1539381

WHO. (2020). Transmission of SARS-CoV-2 : implications for infection prevention precautions. July, $1-10$ 